\title{
Biogeographic Overview of Ulmaceae: Diversity, Distribution, Ecological Preferences, and Conservation Status
}

\author{
Yann Fragnière ${ }^{1} \mathbb{D}$, Yi-Gang Song ${ }^{2} \mathbb{D}$, Laurence Fazan ${ }^{1}$, Steven R. Manchester ${ }^{3}$, Giuseppe Garfi ${ }^{4} \mathbb{D}$ and \\ Gregor Kozlowski 1,2,5,*(D) \\ 1 Department of Biology and Botanic Garden, University of Fribourg, Chemin du Musée 10, \\ CH-1700 Fribourg, Switzerland; yann.fragniere@unifr.ch (Y.F.); laurence.fazan@unifr.ch (L.F.) \\ 2 Eastern China Conservation Centre for Wild Endangered Plant Resources, Shanghai Chenshan Botanical \\ Garden, 3888 Chenhua Road, Songiiang, Shanghai 201602, China; ygsong@cemps.ac.cn \\ 3 Florida Museum of Natural History, University of Florida, 1659 Museum Rd, Gainesville, FL 32611, USA; \\ steven@flmnh.ufl.edu \\ 4 Institute of Biosciences and BioResources-National Research Council, Corso Calatafimi 414, \\ 90129 Palermo, Italy; giuseppe.garfi@ibbr.cnr.it \\ 5 Natural History Museum Fribourg, Chemin du Musée 6, CH-1700 Fribourg, Switzerland \\ * Correspondence: gregor.kozlowski@unifr.ch; Tel.: +41-26-300-88-42
}

Citation: Fragnière, Y.; Song, Y.-G.; Fazan, L.; Manchester, S.R.; Garfi, G.; Kozlowski, G. Biogeographic Overview of Ulmaceae: Diversity, Distribution, Ecological Preferences, and Conservation Status. Plants 2021, 10, 1111. https://doi.org/10.3390/ plants10061111

Academic Editor: Stefan Zerbe

Received: 6 April 2021

Accepted: 27 May 2021

Published: 31 May 2021

Publisher's Note: MDPI stays neutral with regard to jurisdictional claims in published maps and institutional affiliations.

Copyright: (C) 2021 by the authors Licensee MDPI, Basel, Switzerland. This article is an open access article distributed under the terms and conditions of the Creative Commons Attribution (CC BY) license (https:/ / creativecommons.org/licenses/by/ $4.0 /)$.

\begin{abstract}
The elm family (Ulmaceae) is a woody plant group with important scientific, societal, and economic value. We aim to present the first biogeographic synthesis investigating the global diversity, distribution, ecological preferences, and the conservation status of Ulmaceae. A literature review was performed to explore the available data for all extant species. Our study made it possible to map the actual global distribution of Ulmaceae with high precision, and to elucidate the centers of diversity, located mainly in China and in the southeastern USA. A detailed comparative analysis of the macroclimatic niche for each species was produced, which shows the general biogeographic pattern of the family and pinpoints the outlier species. The results corroborate recent molecular analyses and support the division of Ulmaceae into two taxonomically, biogeographically, and ecologically well-differentiated groups: the so-called temperate clade with 4 genera and 43 species and the tropical clade with 3 genera and 13 species. The elm family is often described as a typical temperate plant group, however the diversity peak of all Ulmaceae is located in the subtropical zone, and a non-negligible part of the family is exclusively distributed in the tropics. We also noticed that a high proportion of Ulmaceae is linked to humid macro- or microhabitats. Finally, we highlighted that nearly $25 \%$ of all Ulmaceae are threatened. Fieldwork, conservation efforts, and research activities are still necessary for this family, particularly for the tropical members and the most endangered species.
\end{abstract}

Keywords: climatic niche; diversity centers; elm family; Köppen-Geiger climate classification; latitudinal diversity gradient; relict trees

\section{Introduction}

Although ranking among the smallest families in the plant kingdom in terms of the number of species, the elm family (Ulmaceae) has important scientific, economic, societal, and conservation value [1,2]. Ulmaceae is an ancient and exclusively woody plant group consisting of deciduous, rarely evergreen trees and shrubs [3-5]. It is an extremely interesting plant family with respect to different scientific issues, such as paleobotany, biogeography, systematics, plant evolution, or species diversification. However, though considered a relatively well known plant group, many of its representatives, especially from the tropical regions, still remain insufficiently investigated, e.g., [6,7].

Ulmaceae includes many relict trees. Fossil records date the origin of the family to the early Cenozoic Era. By the early Paleocene, members of the elm family were already widespread throughout the entire Northern Hemisphere [8,9], but the oldest confirmed 
records of extant genera, such as Ulmus and Zelkova, are from the Eocene. At least one widespread genus went extinct, i.e., Cedrelospermum, from the Paleogene and Neogene of Europe, Asia, and North America [10,11]. Other genera, common in the past at the continental scale, persist at present in disjunct (e.g., Zelkova, growing in Eastern Asia and South-Western Eurasia) [1] or in restricted distribution areas (e.g., Hemiptelea, thriving in several localities of Korea and eastern China) [12]. The oldest fossils of living genera consist of leaves and fruits of Ulmus referred to the early Eocene of China (ca. 50 Mya) and the middle to late Eocene of North America [13].

The systematics of elm family has had a very controversial story. It was taxonomically described for the first time in 1815 by de Mirbel [14] and contained at that time only two genera, Ulmus and Celtis. Subsequently, for nearly 150 years, the family was commonly divided into two subgroups associated with each of these original genera [8]. Until the late 1990s, two subfamilies of Ulmaceae were recognized, the Ulmoideae and the Celtidoideae, often denominated as "ulmoids" and "celtoids," respectively [15], though at the end of the 1960s Grudzinskaya [16] had proposed distinguishing two different families within the family Ulmaceae, the Ulmaceae s.s. and the Celtidaceae. At that time, the number of genera included in the elm family ranged between 15 and $18[8,9]$. The clarification of the taxonomic division of this group came with the molecular phylogenies performed on all closely related urticoid families of the order Rosales, mainly on Cannabaceae. The modern circumscription of Cannabaceae resulted in the integration of the majority of celtoids into this family (e.g., Celtis, Pteroceltis, Trema, Aphananthe, and Lozanella) and their exclusion from Ulmaceae $[15,17]$. Furthermore, the genus Ampelocera, treated previously as a member of Celtidoideae $[8,18]$, was recognized as an ulmoid taxon $[6,15,19]$.

Modern treatments based on molecular phylogenies therefore clearly separate Cannabaceae and Ulmaceae [15,18-21]. Moreover, Cannabaceae is a sister family to Moraceae and Urticaceae and thus is not the closest taxon of Ulmaceae within the urticalean rosids [17,20,22]. Moreover, recent molecular studies [23,24] divide the Ulmaceae into two distinct taxonomic and biogeographic groups: the temperate clade (including Ulmus, Zelkova, Planera, and Hemiptelea) and the tropical clade (including Ampelocera, Phyllostylon, and Holoptelea).

Ulmaceae possess very distinctive fruit structures (and corresponding dispersal mechanisms), which provide interesting elements to outline the evolutionary pathways within the family [16], in addition to being extremely important for the identification of extant and extinct genera and species [8]. The asymmetric akene-type, unwinged fruit of Zelkova is suggested as being the most primitive fruit-type within the family. At the opposite, the genera Ulmus, Hemiptelea, Holoptelea, and Phyllostylon have the most evolved winged fruits and are thus clearly wind-dispersed [9]. However, the dispersal mechanisms of Hemiptelea need more investigation, since its small asymmetric fruits possess a wing-like appendix only on one side of the fruit [3], and for this reason it can be referred to as an intermediate step in the evolutionary pathway of the family. Planera have fleshy protuberances, and since they grow mainly along water courses, the tree is probably water dispersed [9]. The members of the neotropical Ampelocera possess ellipsoid or even pyriform drupes, which in certain species can be relatively large and colored (e.g., A. macrocarpa) and are primarily bird-dispersed [6]. The most sophisticated, however, seems to be the dispersal mechanisms in the genus Zelkova due to the drupaceous and unwinged features of its individual fruits. In fact, mature fruits commonly fall with the entire twig, and the dried leaves that are still attached function as a drag-enhancing appendage, carrying the fruits away from the parent tree $[25,26]$.

The members of Ulmaceae show a variety of breeding systems and floral types [27]. Some genera, such as Zelkova or Planera, exhibit three flower types (staminate, pistillate, and hermaphrodite flowers) on the same individual or even on the same flowering branch $[27,28]$. Similar to other closely related families belonging to the Urticalean rosids, the flowers of Ulmaceae have only one whorl of 4-8 green or brown perianth lobes (denominated either as sepals or tepals). Stamens usually show the same number as tepals (with 
the exception of Holoptelea and Ampelocera with up to 12 or 16 stamens, respectively) [27]. The superior ovary is composed of two fused carpels with two linear styles [4].

Despite the long history of Ulmaceae research, a synthesis of the diversity and biogeography of this family that takes more recent publications and the current state of knowledge into account has yet to be produced. Information dealing with spatial distributions and biodiversity is central to many fundamental questions in biogeography and conservation biology $[29,30]$. The distribution of different plant taxa (especially families) is basic and essential information fundamental in many studies, but syntheses at global scales are rather scarce [31,32]. Understanding global biogeography is of great importance for the effective conservation of any group of organisms, especially plant families with disjunct distribution patterns [28]. In this paper, we investigate the global diversity, distribution pattern, conservation status, and ecological preferences of the elm family. The aim of the present work is thus to provide an up-to-date synthesis. Our main objectives are to (1) present the actual global distribution of Ulmaceae with the highest possible resolution, (2) contribute to elucidating the diversity hotspots of Ulmaceae at the generic and species levels, (3) elucidate the realized (macro)climatic niche and ecological preferences of all extant Ulmaceae species, and (4) synthesize the conservation status of the elm family.

\section{Results}

\subsection{Taxonomic Division and Species List}

Based on the published taxonomic treatments and available literature (Supplementary file S1), the taxonomic division and number of species of the Ulmaceae family is given in Table 1 . The elm family consists of 56 species, divided into 2 clades (13 in the tropical clade and 43 in the temperate clade) and 7 genera. In general, the information and published literature on the tropical members of the family are sparser than for the temperate species (Supplementary file S1). The following doubtful Ulmus species were not included: $U$. chumlia, treated as a synonym of $U$. androssowii $[33,34]$; $U$. procera, treated as a synonym of U. minor, introduced in North America [34,35]; U. elliptica (Caucasus), treated as a synonym of $U$. glabra $[33,36]$; and $U$. densa (Central Asia), treated as a synonym of $U$. minor $[33,37]$.

Table 1. Summary of the taxonomic division, genera and species number, and general distribution of the elm family (Ulmaceae). \# Species: number of species. Parenthesis: number of species by region.

\begin{tabular}{|c|c|c|c|}
\hline Clade & Genus & \# Species & General Distribution \\
\hline \multirow{3}{*}{ Tropical clade } & Ampelocera & 9 & South America and Mesoamerica (8), Caribbean (1) \\
\hline & Holoptelea & 2 & $\begin{array}{c}\text { Africa (1) } \\
\text { Asia (1) }\end{array}$ \\
\hline & Phyllostylon & 2 & $\begin{array}{c}\text { South America (1) } \\
\text { South America, Mesoamerica and Caribbean (1) }\end{array}$ \\
\hline \multirow{4}{*}{ Temperate clade } & Hemiptelea & 1 & Eastern Asia \\
\hline & Planera & 1 & North America \\
\hline & Ulmus & 35 & $\begin{array}{c}\text { North America (6) } \\
\text { Mesoamerica (2) } \\
\text { Europe and Western Asia (3) } \\
\text { Asia (24) }\end{array}$ \\
\hline & Zelkova & 6 & $\begin{array}{c}\text { Mediterranean Europe and Western Asia (3) } \\
\text { Eastern Asia (3) }\end{array}$ \\
\hline Total & & 56 & \\
\hline
\end{tabular}

\subsection{Species and Genera Distribution}

An up-to-date global distribution map of Ulmaceae was produced, which corresponds to the most actual chorological knowledge of this family with the highest possible resolution (Figure 1). This map combines the individual distribution maps made for each species (see 
Methods). In many areas, the distributions of several species overlap. Several regions can be considered hotspots of Ulmaceae diversity, with numerous species co-occurring in the same area. This is especially true for Eastern Asia. China has the highest diversity worldwide, with 12 species and 3 genera. The main Chinese hotspots are in the following provinces: western Henan, Shanxi, Shaanxi, southern Anhui, western Zhejang, northern Jiangxi, and Hubei. At least three species can be found in all provinces of China (except western provinces and Hainan), in Taiwan, in North and South Korea, in Japan and in the Russian Far East. The southeastern United States is another important Ulmaceae hotspot, mainly in Arkansas (six species and two genera), Tennessee, Louisiana, Mississippi, Alabama, western Kentucky, and eastern Texas. In the majority of Central and Eastern Europe, three Ulmus species co-occur. In the Sub-Himalayan region, up to three Ulmus species can also be found together in India (Kashmir, Himachal Pradesh). In South and Central America, a maximum of three to four Ampelocera species occur together, mainly in eastern Colombia (Choco, Antioquia, Cordoba, and Zulia) and marginally in Brazil (Acre).

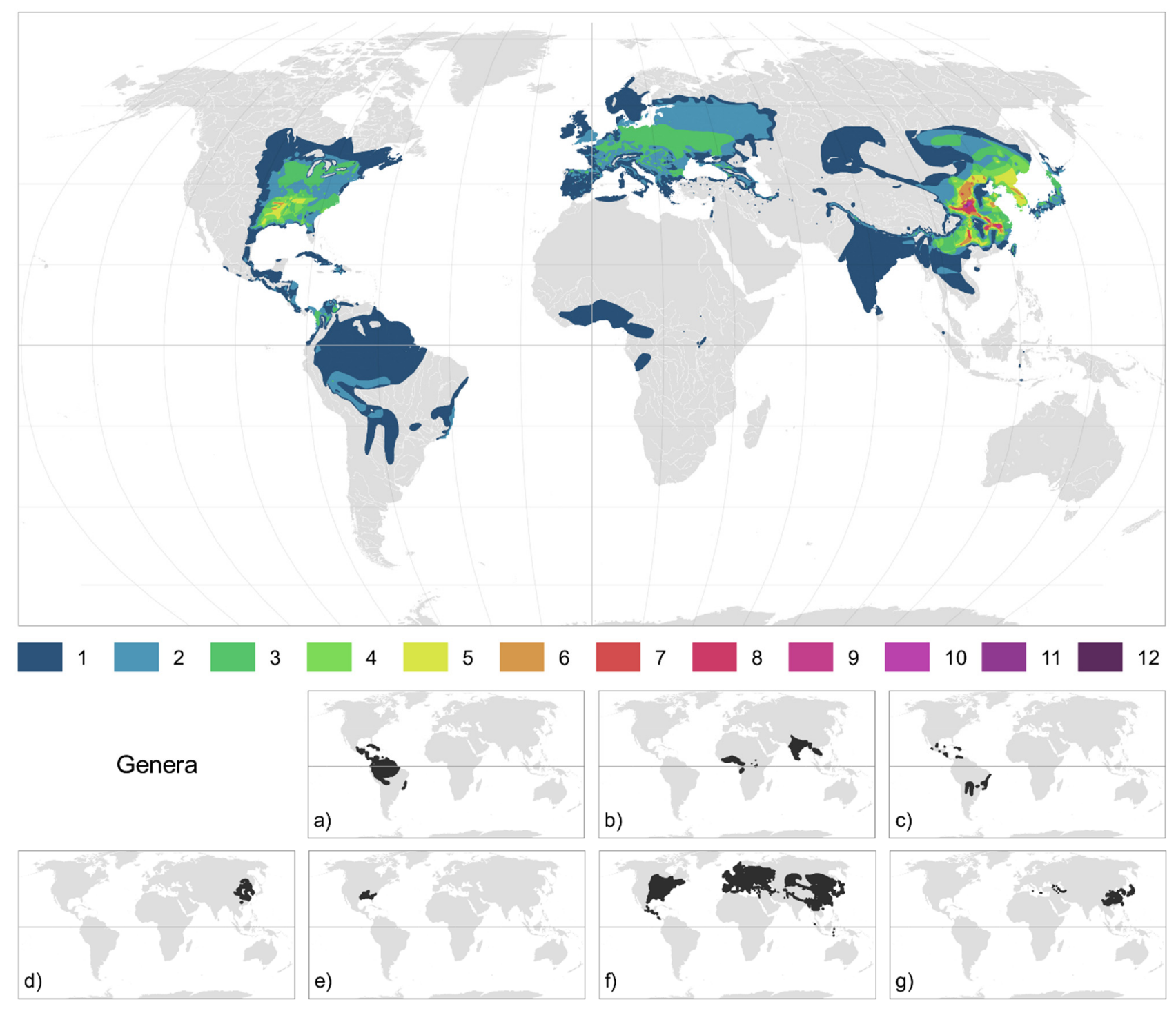

Figure 1. Global distribution of Ulmaceae. The color gradient shows the number of species with overlapping distribution. The small maps below indicate the global distribution of the different genera. Tropical clade: (a) Ampelocera, (b) Holoptelea, and (c) Phyllostylon; Temperate clade: (d) Hemiptelea, (e) Planera, (f) Ulmus, and (g) Zelkova.

The two clades show very different latitudinal diversity patterns (Figure 2). The tropical clade is nearly entirely confined between the tropical lines, with a peak between $5^{\circ}$ 
and $12^{\circ}$ of $\mathrm{N}$ latitude. Only rare species of the temperate clade cross the Tropic of Cancer to the south. The diversity peak of the temperate clade (between $28^{\circ} \mathrm{N}$ and $38^{\circ} \mathrm{N}$ ) is located in the subtropical zone. Ulmaceae extends to the south to approximately $24^{\circ} \mathrm{S}$ (Phyllostylon rhamnoides in South America) and to the north up to approximately $69^{\circ} \mathrm{N}$ (Ulmus glabra in Europe).

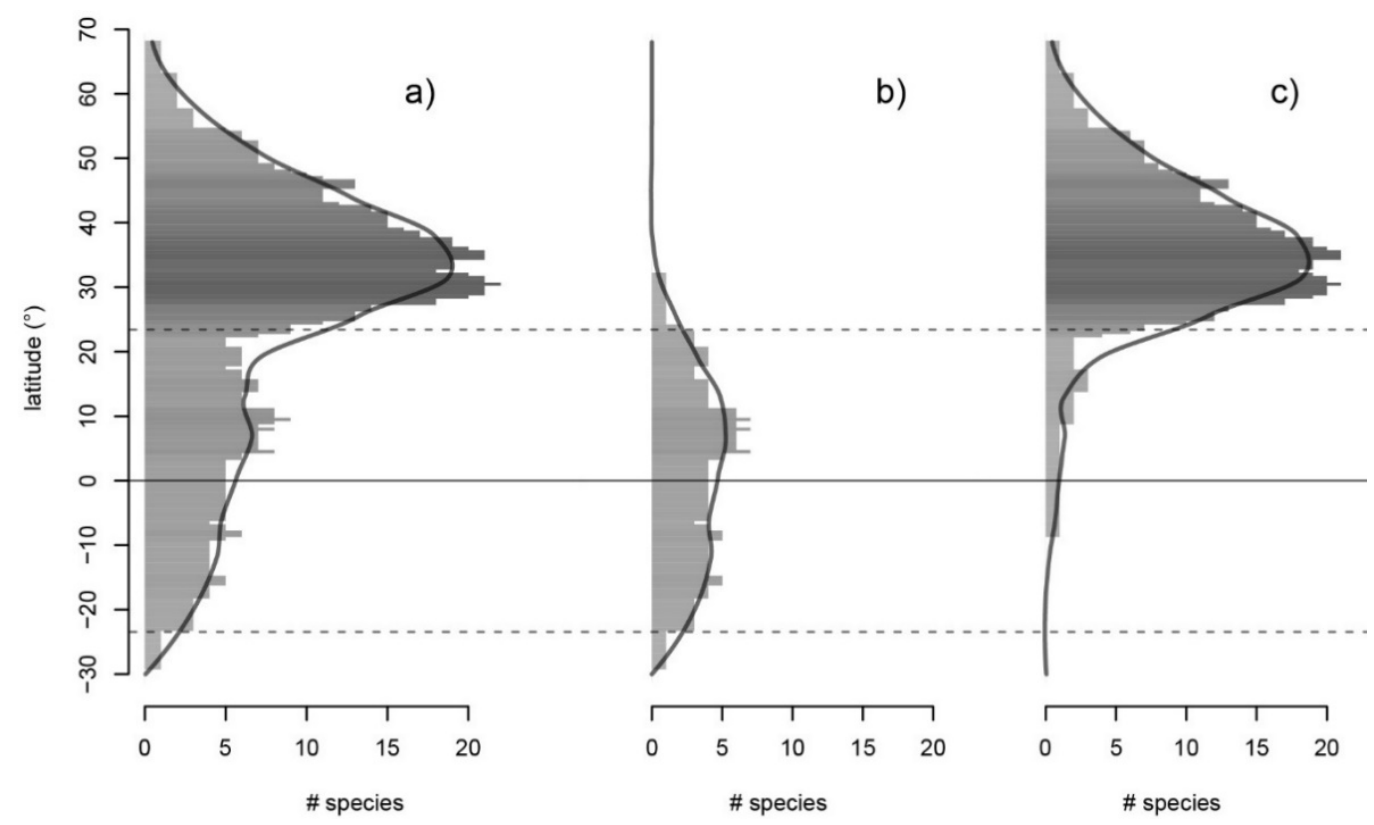

Figure 2. Latitudinal diversity gradient. Species richness by $0.5^{\circ}$ latitudinal bin for (a) the complete Ulmaceae family, (b) the tropical clade and (c) the temperate clade. A smooth approximation is shown by the LOESS (locally estimated scatterplot smoothing) curve above the histogram. The equator is represented by the solid horizontal line, and the tropics are represented by the two dashed lines.

\subsection{Species Macroclimatic Niche and Ecological Preferences}

A detailed overview of the realized macroclimatic niche of all the species of the Ulmaceae family is presented in Figures 3 and 4. Additionally, the ordination plot (Figure 5) allows us to elucidate species that share similar macroclimatic preferences and to highlight outliers. Most of the species of the tropical clade are distributed in areas with tropical climates of (A)f-rainforest, (A)m-monsoon, and (A)w-savannah. The exception is Ampelocera albertiae, growing at a high elevation in the mountains in a rather temperate oceanic climate (Cfb), as well as Phyllostylon rhamnoides and Holoptelea integrifolia found in several climate types, such as BSh (semiarid hot climate), Cwa (dry-winter humid subtropical climate), and Cfa (humid subtropical climate).

The North American members of the temperate clade of Ulmaceae mainly occur in Cfa (humid subtropical climate). Among them, three species also occur in Dfa and Dfb (continental climate without dry season, with warm to hot summer). The European members are mainly in $\mathrm{Cfb}$ (oceanic climate), but some species are found in more Mediterranean and/or continental climates. The Asiatic members of the temperate clade are mainly typical elements of Cfa (humid subtropical climate) but are also very common in Cwa (dry-winter humid subtropical climate) and Cwb (dry-winter subtropical highland climate), as well as in Dwa and Dwb (continental climate, with dry winter and warm to hot summer). The niches of some Asiatic species (Ulmus pumila, U. macrocarpa, and U. davidiana) cover a large gradient of temperatures, including very cold areas, with mean annual temperatures close to or below $0{ }^{\circ} \mathrm{C}$ and sometimes with extreme annual temperature variations (Figure 4). Several species are clear outliers among the temperate clade: the Mexican and Mesoamerican Ulmus species, the East-Asiatic U. lanceifolia and U. uyematsui from Taiwan, and the Mediterranean Zelkova species. 


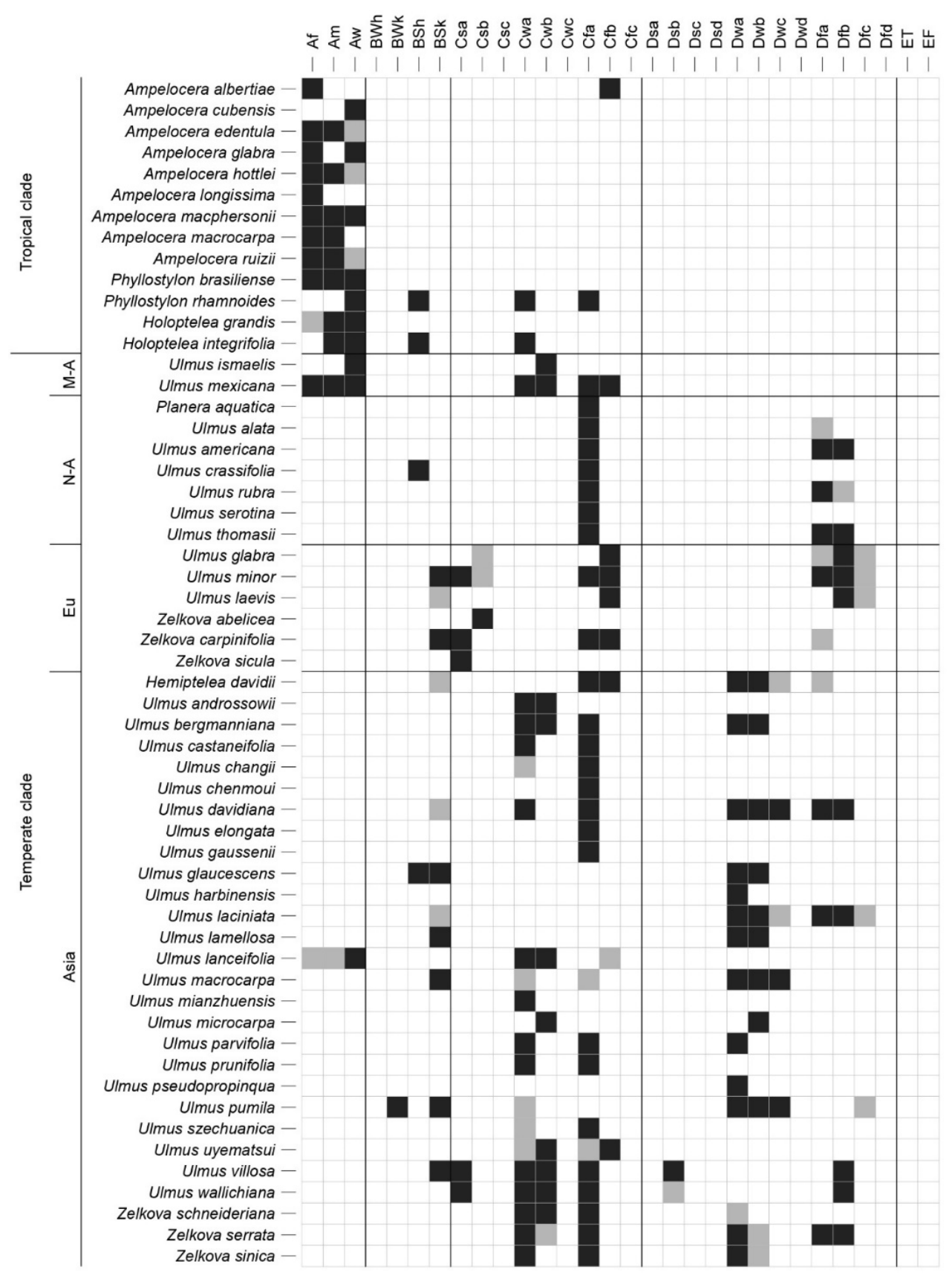

Figure 3. Realized (macro)climatic niches for each species of the Ulmaceae family, according to the Köppen-Geiger climate classification. A black square indicates that a species is largely distributed in the corresponding climate, and a grey square indicates that the species is only marginally distributed in the corresponding climate. The species are presented in the following order from top to bottom: tropical clade and temperate clade, further divided in Mesoamerica (M-A), North America (N-A), Europe (Eu), and Asia. The upper abbreviations indicate the type of climate: tropical rainforest climate (Af), tropical monsoon climate (Am), tropical savanna climate (Aw), arid climate (BW; $\mathrm{h}$-hot, k—cold), semiarid (steppe) climate (BS; h—hot, k—cold), Mediterranean climate (Cs; a - hot summer, b—warm summer, c—cool summer), humid subtropical climate (Cfa), oceanic climate (Cfb), subpolar oceanic climate (Cfc), dry-winter humid subtropical climate (Cwa), dry-winter subtropical highland climate $(\mathrm{Cwb})$, dry-winter subpolar oceanic climate $(\mathrm{Cwc})$, continental climate (D; s-dry summer, $\mathrm{w}$-dry winter, $\mathrm{f}$ - no dry season; a-hot summer, $\mathrm{b}$ - warm summer, $\mathrm{c}$ - cold summer, $\mathrm{d}$-very cold winter), tundra climate (ET), and ice climate (EF). 


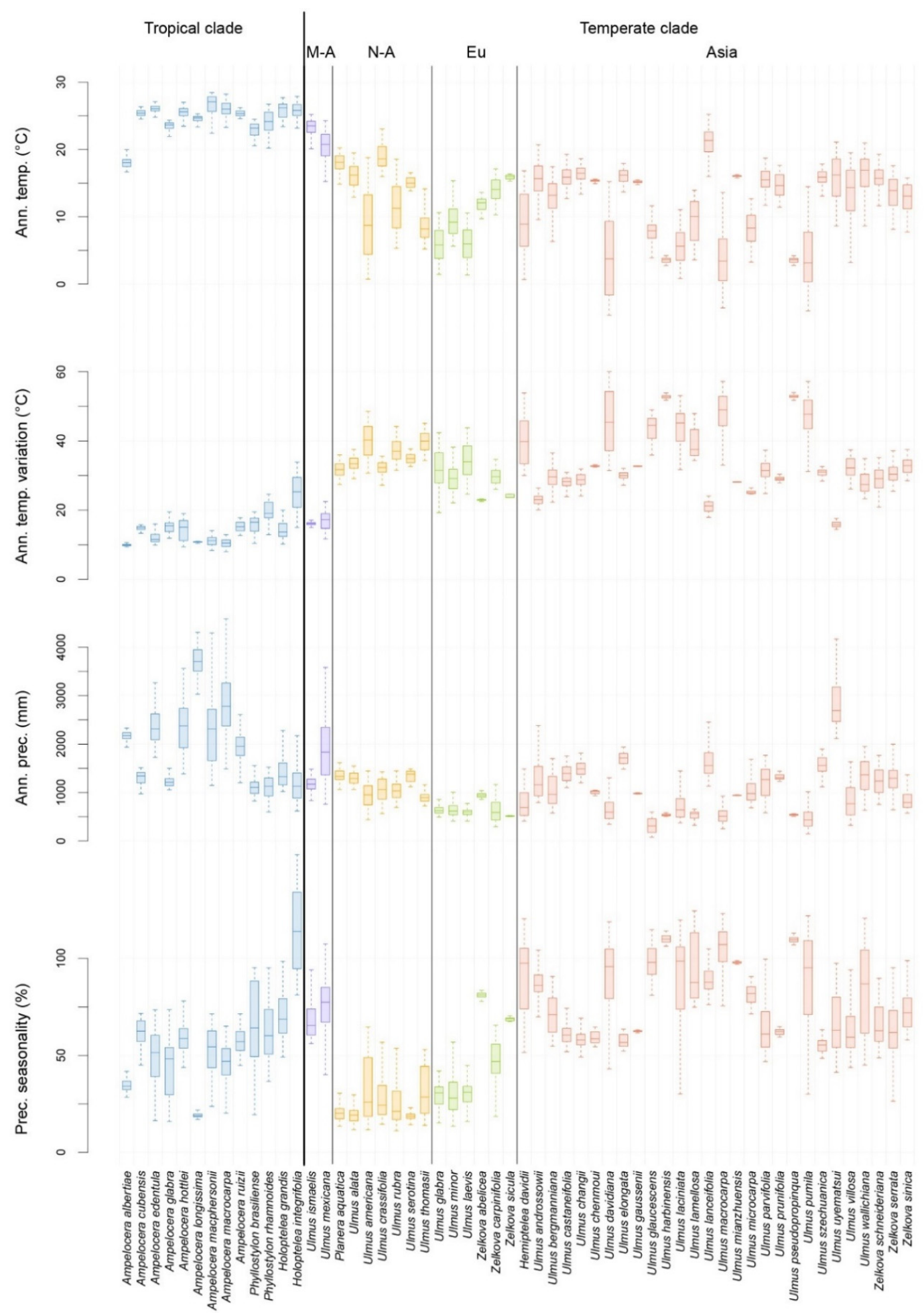

Figure 4. Macroclimatic preferences for each species of the Ulmaceae family according to their natural distribution and for a selection of four climatic variables: mean annual temperature $\left({ }^{\circ} \mathrm{C}\right)$, mean annual temperature variation (maximum temperature of the warmest month-minimum temperature of the coldest month, ${ }^{\circ} \mathrm{C}$ ), mean annual precipitation (mm) and precipitation seasonality (variation in monthly precipitation totals over the course of the year, \%). The species are presented in the following order from left to right: tropical clade and temperate clade, further divided in Mesoamerica (M-A), North America (N-A), Europe (Eu), and Asia. These five groups are indicated by different colors. 


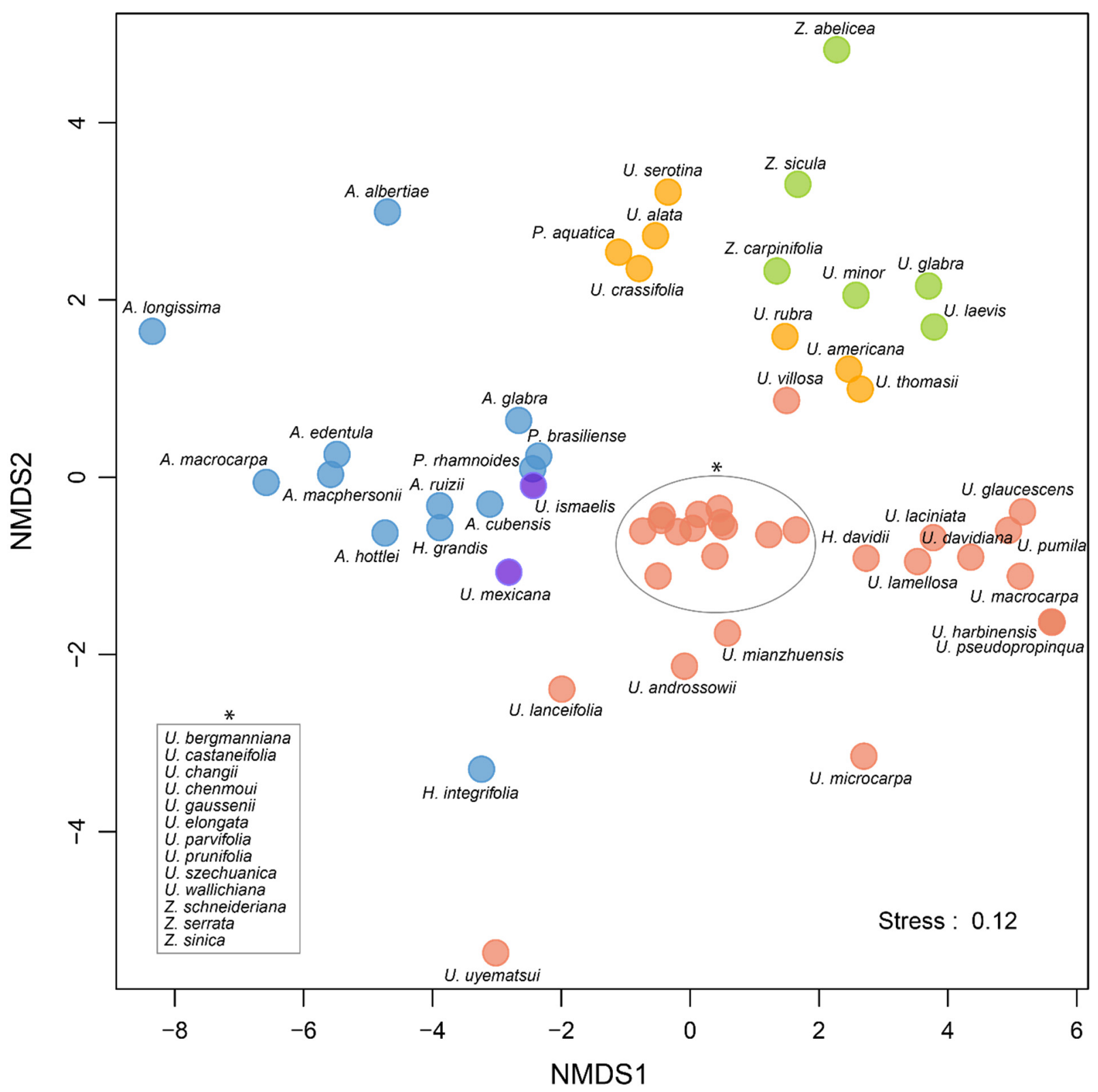

Figure 5. Nonmetric multidimensional scaling (NMDS) ordination plot representing the (macro)climatic similarities between species of the Ulmaceae family. A total of 19 climatic variables were included in the analysis (see Material and Methods). Species appearing close together in the plot share similar macroclimatic preferences. The species are divided into the following groups: tropical clade (blue), temperate clade divided further in Mesoamerica (purple), North America (yellow), Europe (green), and Asia (red).

We collected all available information on the relationship of Ulmaceae species with water and soil conditions (Table 2). Nearly 70\% of species belonging to the elm family occur (obligatorily or facultatively) in wet habitats. A majority of species are typical elements of tropical humid forests (15 spp.) or are found exclusively in alluvial and riparian forests (11 spp.). Additionally, there were a relatively large number of Ulmaceae (13 spp.) that occur (not exclusively) in wet microhabitats. Finally, a significant proportion of Ulmaceae species seem to prefer rich, fertile soils. 
Table 2. Division of Ulmaceae according to their macro- and microhabitats, with a focus on humid habitats. \# Species: number of species.

\begin{tabular}{lcc}
\hline \multicolumn{1}{c}{ Category } & \# Species & $\%$ \\
\hline $\begin{array}{l}\text { Species of humid macrohabitats (equatorial and tropical humid rainforests, large amount }(>1500 \mathrm{~mm}) \\
\text { of annual precipitation) }\end{array}$ & 15 & 26.8 \\
\hline Species of moist microhabitats (alluvial and riparian forests, moist ravines), generally exclusively & 11 & 19.6 \\
\hline Species often occurring in moist microhabitats but also in other habitat types & 13 & 23.2 \\
\hline Species occurring in other habitat types or scarce information available & 17 & 30.4 \\
\hline
\end{tabular}

\subsection{Conservation Status}

Thirty-eight Ulmaceae species are included to date on the IUCN Red List (i.e., $68 \%$ of the total species number). For one-third of all members of the elm family, no global assessment has been made (Table 3). Among the assessed species, two were critically endangered (IUCN category CR), four were endangered (EN), five were vulnerable (VU), and two were near threatened (NT). Thus, $34 \%$ of all assessed species and $23 \%$ of all Ulmaceae species are considered under threat. This group of threatened species includes all six Zelkova species, five Ulmus species, and two Ampelocera species.

Table 3. Conservation status of the Ulmaceae species. IUCN categories: CR—critically endangered, EN-endangered, VU—vulnerable, NT—nearly threatened, LC—least concerned, DD—data deficiency (IUCN 2020). \# Species: number of species.

\begin{tabular}{|c|c|c|}
\hline IUCN Category & \# Species & Species \\
\hline $\mathrm{CR}$ & 2 & Ulmus gaussenii, Zelkova sicula \\
\hline EN & 4 & Ampelocera albertiae, Ulmus americana, U. chenmoui, Zelkova abelicea \\
\hline VU & 5 & Ulmus elongata, U. wallichiana, Zelkova carpinifolia, Z. sinica, Z. schneideriana \\
\hline NT & 2 & Ampelocera longissima, Zelkova serrata \\
\hline $\mathrm{LC}$ & 22 & $\begin{array}{l}\text { Ampelocera edentula, A. hottlei, A. macphersonii, A. macrocarpa, A. ruizii, Hemiptelea davidii, } \\
\text { Holoptelea grandis, Phyllostylon rhamnoides, Planera aquatica, Ulmus alata, U. castaneifolia, U. } \\
\text { crassifolia, U. davidiana, U. laciniata, U. rubra, U. macrocarpa, U. parvifolia, U. pumila, U. } \\
\text { serotina, U. szechuanica, U. thomasii, U. mexicana }\end{array}$ \\
\hline DD & 3 & Ulmus glabra, U. laevis, U. minor \\
\hline Not assessed & 18 & $\begin{array}{l}\text { Ampelocera cubensis, A. glabra, Holoptelea integrifolia, Phyllostylon brasiliense, Ulmus } \\
\text { androssowii, U. bergmanniana, U. changii, U. glaucescens, U. harbinensis, U. ismaelis, U. lamellosa, } \\
\text { U. lanceifolia, U. mianzhuensis, U. microcarpa, U. prunifolia, U. pseudopropinqua, U. uyematsui, } \\
\text { U. villosa }\end{array}$ \\
\hline
\end{tabular}

\section{Discussion}

\subsection{Diversity and Distribution}

Our global synthesis corroborates recent molecular analyses [23,24] and thus strongly supports the division of Ulmaceae into two taxonomically, biogeographically, and ecologically well-differentiated groups: the so-called temperate clade with 43 species and four genera (Hemiptelea, Zelkova, Planera, and Ulmus) and the tropical clade with 13 species and three genera (Holoptelea, Phyllostylon, and Ampelocera). There exists an enormous discrepancy among the number of studies and thus with the exploration and understanding of the biological and evolutionary processes of the temperate species of Ulmaceae in comparison with the tropical species. Therefore, many aspects of the biology, ecology, and phylogenetic relationships of the tropical clade still need much scientific effort $[3,6,7]$. Furthermore, for many tropical species, in-depth fieldwork is still needed to collect sufficient data about their distribution (e.g., neotropical species with large and scattered distribution: Phyl- 
lostylon rhamnoides and Ampelocera macrocarpa) and to better understand and document their ecology.

Better scientific exploration of northern temperate Ulmaceae is closely linked with their use by humans [38-40]. For millennia, temperate Ulmaceae trees played an important role in rural and forested areas, being part of the traditional landscape as trees with multiple uses [36]. This is especially the case of various species of elm (Ulmus) and the keaki tree (Zelkova serrata) in Eastern Asia, which is widely used as an ornamental tree in silviculture and timber production [1]. Interestingly, many tropical species are locally commonly used for wood and tool production (e.g., Phyllostylon brasiliensis) and/or possess high potential for medicinal purposes (e.g., Holoptelea) $[4,41]$ and thus would need an intensification of research efforts.

For similar reasons, the elm family is often described as a nearly exclusively temperate plant group, typical of the Northern Hemisphere [4,9]. Our global synthesis relativizes this assumption. First, the diversity peak of all Ulmaceae is located in the subtropical zone (between $28^{\circ}$ and $38^{\circ} \mathrm{N}$ ) and a non-negligible part of the family (ca. $23 \%$ of all species) is exclusively distributed in the tropics (the so-called tropical clade). Additionally, several members of the temperate clade are present or even endemic to tropical regions (e.g., Ulmus ismaelis and U. mexicana in Mexico; and U. parvifolia, U. uyematsui, or Zelkova schneideriana in Taiwan). One member of the temperate clade reaches the Southern Hemisphere (Ulmus lanceifolia distributed to the south on the Celebes and Flores islands).

One of the most famous large-scale patterns in biological diversity is the increase in the number of species from the poles to the equator, a trend that has been called the latitudinal diversity gradient (LDG) [29,42]. On a large scale, only a few plant groups do not follow this pattern, such as Poaceae [43] and gymnosperms [31]. Ulmaceae, as a whole, do not exhibit a typical LDG because they have a diversity peak between $28^{\circ}$ and $38^{\circ}$ of northern latitude (Figure 2). This does not seem to be an unusual pattern in small woody families, with predominantly temperate and relict species (e.g., Juglandaceae, [32]). However, the typical LDG with a peak close to the equator can be observed when only the tropical clade of Ulmaceae is taken into consideration (Figure 2b).

Interestingly, the elm family shows a very similar biogeographical pattern and distribution of diversity centers with other exclusively woody plant families that are rich in relict trees, such as the walnut family (Juglandaceae) [5,32]. Similar to Juglandaceae, the main diversity center of Ulmaceae lies in southeastern Asia (mainly in China) followed by a second center in the southeastern USA and a third in Mesoamerica and northern South America (Figure 1).

Moreover, the fossil record demonstrates prior extirpations and extinction in the history of Ulmaceae, possibly reflecting the response to prior climate change. For example, Hemiptelea, which is now endemic to eastern China and the Korean Peninsula, has been confirmed on the basis of its distinctive fossil fruits from the Miocene of Poland and Ukraine (see references in [44]). Although Ulmus is no longer native to west-coastal North America, the genus was well established and identifiable from fruits, as well as leaves, in the Eocene to Miocene of California, Oregon, Washington, and British Columbia [8,45]. Cedrelospermum was widespread in the Eocene of North America, Europe and Asia and extended well south into the later Cenozoic [46]. The cause of its global extinction remains uncertain.

\subsection{Macroclimatic Niche and Ecological Preferences}

Our study shows strong differentiation of the macroclimatic niche between the tropical and temperate clades of Ulmaceae (Figures 3-5). Most of the species of the tropical clade are typical elements of tropical and monsoon forests or of savannah. They are thus distributed in tropical climates with a mean annual temperature generally between $20{ }^{\circ} \mathrm{C}$ and $28{ }^{\circ} \mathrm{C}$, with very low seasonal variation and annual precipitation that are normally over $1000 \mathrm{~mm}$ per year and up to $4000 \mathrm{~mm}$ per year for some species in specific regions (e.g., Ampelocera longissima, A. macphersonii, and A. macrocarpa). There are several exceptions, however, with species occupying niches in temperate regions (e.g., in upland areas, Ampelocera 
albertiae) and/or semiarid hot regions (Phyllostylon rhamnoides and Holoptelea integrifolia). Interestingly, a majority of tropical Ulmaceae possess large leaves (often having entire margins), in contrast to the smaller and usually dentate leaves of temperate genera [6]. This is often interpreted as an adaptation to wet, tropical forest habitats [15]. However, due to the lack of fossil records of the disjunct genera and species of the tropical Ulmaceae clade, their origin and the history of adaptation to tropical climates are less well understood [8].

Similarly, there are also some species of the temperate clade occurring within tropical climates (not exclusively), such as the Ulmus species of Mexico and Mesoamerica ( $U$. mexicana and $U$. ismaelis) and one species in Eastern Asia (U. lanceifolia). These three species are close to the tropical clade in terms of climatic preferences (Figures 4 and 5). North American members of the temperate clade are mainly linked to the humid subtropical climate and in the north to a moderate and humid continental climate. Their climatic niches are generally close to those of European species, but the latter occur in slightly cooler oceanic and continental climates with less precipitation. In Europe, Zelkova abelicea and Z. sicula are the two notable exceptions among the members of the temperate clade (Figures 4 and 5). They occur within a Mediterranean climate with high precipitation seasonality and dry summers. Recent detailed studies on Z. sicula show that this relict and narrow endemic species is isolated and restricted to the Mediterranean climate. The species survived in this region due to suitable microhabitats, but its distribution and dispersal are limited by the Mediterranean climate [47]. Our results highlight that Zelkova species found in Mediterranean climates are exceptions among the Ulmaceae.

In Asia, the numerous species of the temperate clade occupy diverse climatic niches with a large gradient of climatic preferences. There is one constant, however, namely, the high precipitation seasonality due to the East Asian monsoon regime, with dry winters. Some notable outliers are Ulmus uyematsui (distributed in the mountains of Taiwan, with precipitation between 2000 and $4000 \mathrm{~mm}$ per year), as well as $U$. pumila, U. davidiana, and $U$. macrocarpa. The last three species possess a broad climatic range, are cold resistant, and occur in monsoon-influenced climates with high seasonality of temperature and precipitation. Our results show that $U$. pumila has a particularly large climatic plasticity among Ulmaceae in terms of temperature and seasonality. It is also one of the most droughtresistant species among the families. These characteristics make this species well adapted for many anthropogenic habitats and probably explain why $U$. pumila is the main species of Ulmaceae reported as invasive [48].

Reliable and precise information about the ecology of the different species of Ulmaceae is scarce, especially for species growing in the tropics or in Asia. Our synthetized compilation (Table 3) demonstrates, however, that a high proportion of Ulmaceae (70\%) is linked to humid macro- or microhabitats. This proportion may even be higher, as precise information is missing for many species. Notably, more than $26 \%$ of Ulmaceae occur exclusively in tropical humid forests with large amounts of precipitation, higher than $1500 \mathrm{~mm}$ per year (e.g., several Ampelocera and tropical Ulmus species). Moreover, nearly 20\% of Ulmaceae are trees exclusive to alluvial and riparian forests or found growing only along river and stream banks. The best examples are North American Planera aquatica and Ulmus americana, growing exclusively in swamps, along the shores and banks of lakes and rivers and in alluvial flood plains, thus supporting well-waterlogged conditions [49]. In Europe, similar ecological preferences are found for Ulmus laevis, which occurs exclusively in riparian forests along large rivers [36]. The two other European Ulmus species are also frequently found in alluvial woods, although not exclusively. Furthermore, all six Zelkova species are linked to humid habitat conditions to a certain level. East Asiatic Zelkova species are particularly common in forests in mountainous regions with high precipitation, as well as in humid ravines and along streams and rivers [1]. This ecological preference is even more pronounced for the Mediterranean members of the genus, with Z. sicula growing exclusively along a thalweg, filled in winter with water [47]; and to a lesser extent with Z. abelicea, forming large populations only in mountainous areas around winter-moist dolines, summer dry riverbeds or on northern slopes [50]. 


\subsection{Threats and Conservation Status}

Nearly one-fourth of all the Ulmaceae species are threatened according to the IUCN Red List (Table 3). Two Ulmaceae species are on the brink of extinction: the Anhui elm (Ulmus gaussenii) and the Sicilian zelkova (Zelkova sicula) [51,52]. Ulmus gaussenii is a narrow endemic species growing in Langya Mountain in Anhui Province of Eastern China [53]. Due to low fertility and habitat destruction, the number of individuals has drastically decreased in recent decades. This is probably the rarest Ulmaceae of the world, since only 26 mature and senescing individual trees are known, growing in a single population and covering an area of less than 10 hectares [54]. Zelkova sicula, discovered only in 1991, is also a narrow endemic, occurring only in the Iblei Mountains on the Mediterranean island of Sicily in Italy [52]. The species is known from only two populations, $17 \mathrm{~km}$ apart, consisting together of ca. 1860 individuals and covering an extremely small total area of only 0.68 hectares [55]. Furthermore, recent molecular investigations revealed that each population is clonal and considered to be issuing centuries-long sprouting of two single surviving genetic individuals [56,57].

More generally, the genus Zelkova is the most endangered group of the elm family, since, in addition to $Z$. sicula, all other members of the genus are endangered (IUCN category EN, Z. abelicea), vulnerable (VU, Z. carpinifolia, Z. sinica, and Z. schneideriana) or nearly threatened (NT, Z. serrata) according to the IUCN Red List [28,58]. Particularly worrying is the situation of $Z$. abelicea, an endemic species of the Mediterranean island of Crete in Greece [1]. In this species, only well-developed trees can produce fruits. However, the overwhelming majority of individuals are dwarfed and nonfruiting due to overbrowsing by goats [50]. Additionally, the majority of fruit are empty, which is probably due to unfavorable climatic conditions such as pronounced and recurrent droughts [5]. The regeneration of populations via seedlings is nearly impossible due to overgrazing, trampling and soil erosion caused by omnipresent large caprine and ovine flocks [59].

In the genus Ulmus, two species are endangered (EN, U. americana and U. chenmoui), and two species are vulnerable (VU, U. elongata and U. wallichiana). Although American elm (U. americana) still forms large populations in the western parts of the USA and Canada, it is the most susceptible North American elm species to introduced and invasive Dutch elm disease (DED), caused by the fungi Ophiostoma ulmi and O. novo-ulmi $[58,60]$. The population decline during the next 100 years is supposed to reach up to $80 \%$ due to the continuing threat of DED and due to the destruction of its preferred habitat [60]. European elms were also severely impacted by the DED with a severe mortality [38]. Their conservation status is unclear and should be studied in detail. The other three threatened Ulmus species occur in Asia. Ulmus chenmoui and U. elongata are endemic to China, the number of their populations is very restricted, and their original habitat has been largely destroyed [58,61,62]. Ulmus wallichiana is widely distributed in the Himalayan region (Afghanistan, Pakistan, India, and Nepal). However, the species is excessively exploited for fodder and fuel wood, and mature reproducing individuals are extremely rare [63].

Among the neotropical Ulmaceae, Ampelocera albertiae (IUCN category endangered, EN, [64]) is the most threatened species. This species is a narrow endemic of Colombia, known from only five populations and is heavily affected by cattle ranching, mining activities, and artificial forest plantations.

Several additional Ulmaceae species that have not yet been assessed and thus are not included on the IUCN Red List [58] have a high probability of being globally threatened. This is probably the case for Mexican/Mesoamerican Ulmus ismaelis [65]. The taxon is known only from very few and highly isolated populations in Mexico, Salvador, and Honduras [66]. Similarly, numerous Chinese Ulmus species possess very restricted distribution areas (e.g., U. harbinensis, U. lamellosa, U. mianzhuensis, U. prunifolia, and U. pseudopropinqua), and/or their populations are decreasing due to environmental degradation and habitat loss [67].

Ulmaceae is an evolutionarily ancient family possessing high scientific and conservation value. Much more fieldwork, research, and conservation efforts should be undertaken, 
especially within the tropical clade and for threatened species with restricted distributions and/or weak biological and ecological knowledge.

\section{Materials and Methods}

\subsection{Taxonomic Division and Species List}

The generic division of Ulmaceae was based on recent taxonomic treatments and molecular analyses $[10,15,18-21,23,24,68]$. The order of the genera in our study follows the phylogenetic trees of Manchester and Tiffney [68] and Jia et al. [10], dividing the elm family into two clades: (1) a tropical clade with Ampelocera, Phyllostylon, and Holoptelea and (2) a temperate clade with Hemiptelea, Zelkova, Planera, and Ulmus.

The species numbers of the poorly studied neotropical genera Ampelocera and Phyllostyllon were extracted from two detailed monographies by Todzia [6,7], whereas for the third tropical genus, Holoptelea, information was obtained from Boratynska [3] and Todzia [9]. Two genera of the temperate clade, Planera and Hemiptelea, are monotypic $[3,9,49,69]$. The species number of the genus Zelkova was based on taxonomic and biogeographic compilations and recent molecular studies $[1,28,57,70]$. The most challenging issue is the taxonomic division of the species-rich genus Ulmus. In our study, we extracted taxonomic information from eFloras.org: Flora of China, Flora of North America, Flora of Pakistan, Flora Mesoamericana $[49,69,71,72]$, and several other biogeographic treatments and molecular studies $[3,18,36,65,73,74]$. We worked at the species level and did not distinguish between subspecies or varieties.

\subsection{Data Collection}

A literature review was performed to explore the available data about the distribution, ecology, and conservation status of all extant species. Our review protocol was based on Xiao and Watson [75]. We took advantage of open-access online resources, recently published monographs and articles in diverse fields, where useful information could be found. The grey literature was also occasionally consulted. For online research, we used the species names as keyword, alone or accompanied by words like "distribution", "map", "ecology", "habitat", etc. References with inaccurate data (e.g., commercial horticultural websites, personal websites) were excluded in the process. We assessed the quality of the data mainly by crossing them. When the information was concordant and apparently not of the same origin, the references were not excluded. When there was no concordance, we only kept the most reliable sources (known institutions, peer reviewed articles, monographs). All kind of data were taken into account and extracted (maps, tables, texts). The full list of references for each species can be found in Supplementary file S1 in Supplementary material. The authors of all Latin names for Ulmaceae species included in this study, are given in Supplementary file S2. The most important resources are cited here $[6,7,12,28,33,36,49,58,69,76-83]$. The conservation status assessments and information on threats were taken from the IUCN Red List [58].

\subsection{Species Distribution}

Distribution maps for each species were georeferenced and produced on GIS (geographic information system) software [84]. The map background comes from different sources $[85,86]$. The distribution area of each species was determined using literature data, but to improve the reliability and to obtain the most parsimonious results, we also crossed the data with other information such as altitude or climate. The latter was considered by using the Köppen-Geiger climate classification system [87], which was recently made available at a $1 \mathrm{~km}$ resolution [88]. The altitudinal data (30 arc-second resolution) were downloaded from WorldClim version 2.1 [89] and are derived from the Shuttle Radar Topography Mission (SRTM) [90]. Finally, for some species, local experts were asked to examine the distribution maps. Only the natural range was considered, although for some species that have been widely planted, this delimitation was not obvious (Supplementary file S2). 


\subsection{Species Macroclimatic Niche}

The distribution of each species was used to assess the realized climatic niche of natural populations. Global data of 19 bioclimatic variables (e.g., mean annual temperature and precipitation, seasonality; the full list of variables is shown in Supplementary file S3) were downloaded from WorldClim at a high resolution (30 arc-seconds) for the 19702000 period [91]. For each species, we generated 1000 random points in the area of its distribution, where climatic data were extracted. For each variable, we only kept data between the 5th and 95th percentiles to perform the analyses to remove unwanted outliers due to imprecision in species distributions and for more caution in the evaluation of species climatic preferences. The resolution of the climatic data ( 30 arc-seconds, $\sim 1 \mathrm{~km}$ ) does not capture microclimates (e.g., in ravines and slopes), which have been found to be important for some species (e.g., Zelkova abelicea, [92]). We therefore must consider that our analyses represent macroclimatic preferences.

The different Köppen-Geiger climates were also recorded for each species, according to its distribution. The Köppen-Geiger climate classification system uses a 2- or 3-letter abbreviation to designate each climate type $[87,88]$. The first letter indicates the main climate: A-tropical, B-arid, C-temperate, D-cold, and E-polar. The second letter indicates the seasonal precipitation type: $\mathrm{m}$-monsoon, $\mathrm{w}$-savannah, $\mathrm{W}-\mathrm{desert}, \mathrm{S}-$ steppe, $\mathrm{s}-$ dry summer, $\mathrm{w}-$ dry winter, and $\mathrm{f}-$ no dry season. The third letter gives precision regarding the temperature $(\mathrm{h}-\mathrm{hot}, \mathrm{k}$ - cold, $\mathrm{a}$ - hot summer, $\mathrm{b}$ - warm summer, c-cold summer, and d-very cold winter).

\subsection{Statistical Analyses}

All data analyses and graphs were performed with R [93]. Ordination was performed with the nonmetric multidimensional scaling procedure (NMDS) using the package vegan [94-96]. The 19 climatic variables available in WorldClim were included in the analysis (see Supplementary file S3). Precipitation data were square-root transformed, and all climatic data were standardized before performing NMDS, with the Euclidean distance as the distance measure.

Supplementary Materials: The following are available online at https:/ /www.mdpi.com/article/10 $.3390 /$ plants10061111/s1, Supplementary file S1: Full list of references for the distribution of each species, Supplementary file S2: Chorological maps of all Ulmaceae species, Supplementary file S3: List of bioclimatic variables.

Author Contributions: Conceptualization, Y.F. and G.K.; collection and analysis of data, Y.F.; writing, review and editing, Y.F., G.K., Y.-G.S., L.F., G.G. and S.R.M. All authors have read and agreed to the published version of the manuscript.

Funding: Fondation Franklinia (G.K., L.F.).

Institutional Review Board Statement: Not applicable.

Informed Consent Statement: Not applicable.

Data Availability Statement: Data available from the Zenodo open-access repository: https: / doi. org/10.5281/zenodo.4600469, (accessed on 1 April 2021).

Acknowledgments: We would like to thank the Fondation Franklinia and the team of the Botanic Garden of the University of Fribourg (Switzerland) for their support and help in preparation of the manuscript.

Conflicts of Interest: The authors declare no conflict of interest.

\section{References}

1. Kozlowski, G.; Bétrisey, S.; Song, Y.-G.; Fazan, L.; Garfi, G. The Red List of Zelkova; Natural History Museum Fribourg: Fribourg, Switzerland, 2018; ISBN 2-9701096-2-X.

2. Simpson, M.G. Plant Systematics, 3rd ed.; Elsevier: Amsterdam, The Netherlands, 2019; ISBN 0-12-812628-0.

3. Boratynska, K. Chorology of the family ulmaceae (sensu stricto). Arbor Kornikie 1989, 34, 3-29. 
4. Christenhusz, M.J.; Fay, M.F.; Chase, M.W. Plants of the World: An Illustrated Encyclopedia of Vascular Plants; University of Chicago Press: Chicago, IL, USA, 2017; ISBN 0-226-53670-X.

5. Fazan, L.; Song, Y.-G.; Kozlowski, G. The woody planet: From past triumph to manmade decline. Plants 2020, 9, 1593. [CrossRef]

6. Todzia, C.A. A Revision of Ampelocera (Ulmaceae). Ann. Mo. Bot. Gard. 1989, 76, 1087-1102. [CrossRef]

7. Todzia, C.A. A Reevaluation of the genus Phyllostylon (Ulmaceae). SIDA Contribut. Bot. 1992, 15, $263-270$.

8. Manchester, S.R. Systematics and fossil history of the Ulmaceae. Evolut. Syst. Foss. Hist. Hamamelidae 1989, 2, $221-251$.

9. Todzia, C.A. Ulmaceae. In Flowering Plants-Dicotyledons; Springer: Berlin/Heidelberg, Germany, $1993 ;$ pp. 603-611.

10. Jia, L.-B.; Manchester, S.R.; Su, T.; Xing, Y.-W.; Chen, W.-Y.; Huang, Y.-J.; Zhou, Z.-K. First occurrence of Cedrelospermum (Ulmaceae) in Asia and its biogeographic implications. J. Plant Res. 2015, 128, 747-761. [CrossRef] [PubMed]

11. Jia, L.-B.; Su, T.; Huang, Y.-J.; Wu, F.-X.; Deng, T.; Zhou, Z.-K. First fossil record of Cedrelospermum (Ulmaceae) from the Qinghai-Tibetan plateau: Implications for morphological evolution and biogeography. J. Syst. Evol. 2019, 57, 94-104. [CrossRef]

12. Fang, J.; Wang, Z.; Tang, Z. Atlas of Woody Plants in China: Distribution and Climate; Springer Science \& Business Media: Berlin/Heidelberg, Germany, 2011; Volume 1, ISBN 3-642-15017-9.

13. Wang, Q.; Manchester, S.R.; Li, C.; Geng, B. Fruits and leaves of Ulmus from the paleogene of fushun, Northeastern China. Int. J. Plant Sci. 2010, 171, 221-226. [CrossRef]

14. De Mirbel, C.F.B. Élements de Physiologie Végétale et de Botanique; Magimel: Paris, France, 1815; Volume 1.

15. Wiegrefe, S.J.; Sytsma, K.J.; Guries, R.P. The Ulmaceae, one family or two? Evidence from chloroplast DNA restriction site mapping. Plant Syst. Evol. 1998, 210, 249-270. [CrossRef]

16. Grudzinskaya, I.A. Ulmaceae and reasons for distinguishing celtidoideae as a separate family celtidaceae link. Bot. Zhurn. 1967, 52, 1723-1748.

17. Yang, M.-Q.; van Velzen, R.; Bakker, F.T.; Sattarian, A.; Li, D.-Z.; Yi, T.-S. Molecular phylogenetics and character evolution of Cannabaceae. Taxon 2013, 62, 473-485. [CrossRef]

18. Zavada, M.S.; Kim, M. Phylogenetic analysis of Ulmaceae. Plant Syst. Evol. 1996, 200, 13-20. [CrossRef]

19. Ueda, K.; Kosuge, K.; Tobe, H. A molecular phylogeny of Celtidaceae and Ulmaceae (Urticales) based on RbcL nucleotide sequences. J. Plant Res. 1997, 110, 171-178. [CrossRef]

20. Zhang, S.; Soltis, D.E.; Yang, Y.; Li, D.; Yi, T. Multi-gene analysis provides a well-supported phylogeny of rosales. Mol. Phylogenet. Evol. 2011, 60, 21-28. [CrossRef]

21. Chase, M.W.; Christenhusz, M.J.M.; Fay, M.F.; Byng, J.W.; Judd, W.S.; Soltis, D.E.; Mabberley, D.J.; Sennikov, A.N.; Soltis, P.S.; Stevens, P.F. An update of the angiosperm phylogeny group classification for the orders and families of flowering plants: APG IV. Bot. J. Linn. Soc. 2016, 181, 1-20.

22. Sytsma, K.J.; Morawetz, J.; Pires, J.C.; Nepokroeff, M.; Conti, E.; Zjhra, M.; Hall, J.C.; Chase, M.W. Urticalean rosids: Circumscription, rosid ancestry, and phylogenetics based on RbcL, TrnL-F, and NdhF sequences. Am. J. Bot. 2002, 89, 1531-1546. [CrossRef]

23. Neubig, K.; Herrera, F.; Manchester, S.R.; Abbott, J.R. Fossils, biogeography and dates in an expanded phylogeny of Ulmaceae. In Proceedings of the Botany 2012-Annual Meeting of the Botanical Society of America in Columbus, Columbus, OH, USA, 7-11 July 2012.

24. Zhang, Q.; Deng, M.; Bouchenak-Khelladi, Y.; Zhou, Z.; Hu, G.; Xing, Y. The diversification of the northern temperate woody flora-A case study of the elm family (Ulmaceae) based on phylogenomic and paleobotanical evidence. J. Syst. Evol. 2021. [CrossRef]

25. Oyama, H.; Fuse, O.; Tomimatsu, H.; Seiwa, K. Variable seed behavior increases recruitment success of a hardwood tree, Zelkova Serrata, in spatially heterogeneous forest environments. For. Ecol. Manag. 2018, 415, 1-9. [CrossRef]

26. Certini, D.; Fazan, L.; Nakayama, N.; Viola, I.M.; Kozlowski, G. Velocity of the falling dispersal units in Zelkova abelicea: Remarkable evolutionary conservation within the relict tree genus. Am. J. Bot. 2020. [CrossRef]

27. Leme, F.M.; Staedler, Y.M.; Schönenberger, J.; Teixeira, S.P. Ontogeny and vascularization elucidate the atypical floral structure of Ampelocera Glabra, a tropical species of Ulmaceae. Int. J. Plant Sci. 2018, 179, 461-476. [CrossRef]

28. Kozlowski, G.; Gratzfeld, J. Zelkova-An Ancient Tree: Global Status and Conservation Action; Natural History Museum Fribourg: Fribourg, Switzerland, 2013.

29. Mutke, J.; Barthlott, W. Patterns of vascular plant diversity at continental to global scales. Biol. Skr. 2005, 55, 521-531.

30. Collen, B.; Whitton, F.; Dyer, E.E.; Baillie, J.E.; Cumberlidge, N.; Darwall, W.R.; Pollock, C.; Richman, N.I.; Soulsby, A.-M.; Böhm, M. Global patterns of freshwater species diversity, threat and endemism. Glob. Ecol. Biogeogr. 2014, 23, 40-51. [CrossRef] [PubMed]

31. Fragnière, Y.; Bétrisey, S.; Cardinaux, L.; Stoffel, M.; Kozlowski, G. Fighting their last stand? A global analysis of the distribution and conservation status of gymnosperms. J. Biogeogr. 2015, 42, 809-820. [CrossRef]

32. Song, Y.-G.; Fragnière, Y.; Meng, H.-H.; Li, Y.; Bétrisey, S.; Corrales, A.; Manchester, S.R.; Deng, M.; Jasińska, A.K.; Văn Sâm, H. Global biogeographic synthesis and priority conservation regions of the relict tree family Juglandaceae. J. Biogeogr. 2020, 47, 643-657. [CrossRef]

33. Hassler, M. World plants: Synonymic checklists of the vascular plants of the world (Version Nov 2018). In Species 2000 E ITIS Catalogue of Life, 2020-09-01 Beta; Roskov, Y., Ower, G., Orrell, T., Nicolson, D., Bailly, N., Kirk, P.M., Bourgoin, T., DeWalt, R.E., Decock, W., van Nieukerken, E., et al., Eds.; Naturalis: Leiden, The Netherlands, 2020. 
34. The Plant List A Working List of All Plant Species; Version 1.1. Available online: http:/ / www.theplantlist.org/ (accessed on 15 December 2020).

35. Elbert, L.; Little, J. Checklist of United States Trees (Native and Naturalized); Forest Service, US Department of Agriculture: Washington, DC, USA, 1979.

36. Caudullo, G.; De Rigo, D. Ulmus-elms in Europe: Distribution, habitat, usage and threats. In European Atlas of Forest Tree Species; Publication Office of the European Union: Luxembourg, 2016; pp. 186-188.

37. Seregin, A.P. Digital herbarium of Moscow State University: The largest Russian biodiversity database. Biol. Bull. 2017, 44, 584-590. [CrossRef]

38. Dunn, C.P. The Elms: Breeding, Conservation, and Disease Management; Springer Science \& Business Media: Berlin/Heidelberg, Germany, 2000; ISBN 0-7923-7724-9.

39. Boratyńska, K.; Sękiewicz, M.; Boratyński, A. Morfologia, systematyka i rozmieszczenie geograficzne. In Wiazy (Ulmus); Bugała, W., Boratyński, A., Iszkuło, G., Eds.; Bogucki Wydawnictwo Naukowe: Poznań, Poland, 2015; pp. 24-52.

40. Zhang, Q.; Zhou, Z.; Xing, Y. Phylogeny and biogeographic history of Ulmaceae based on complete chloroplast genome and nuclear sequences. In Proceedings of the 16th National Congress of Botanical Society of China, Kunming, China, 10-13 October 2018.

41. Kumar, V.; Singh, S.; Bhadouria, R.; Singh, R.; Prakash, O. Phytochemical, analytical and medicinal studies of Holoptelea Integrifolia roxb: Planch-A Review. Curr. Tradit. Med. 2019, 5, 270-277. [CrossRef]

42. Hillebrand, H. On the generality of the latitudinal diversity gradient. Am. Nat. 2004, 163, 192-211. [CrossRef]

43. Visser, V.; Clayton, W.D.; Simpson, D.A.; Freckleton, R.P.; Osborne, C.P. Mechanisms driving an unusual latitudinal diversity gradient for grasses. Glob. Ecol. Biogeogr. 2014, 23, 61-75. [CrossRef]

44. Manchester, S.R.; Chen, Z.-D.; Lu, A.-M.; Uemura, K. Eastern Asian endemic seed plant genera and their paleogeographic history throughout the northern hemisphere. J. Syst. Evol. 2009, 47, 1-42. [CrossRef]

45. Denk, T.; Dillhoff, R.M. Ulmus leaves and fruits from the early-middle Eocene of Northwestern North America: Systematics and implications for character evolution within Ulmaceae. Botany 2005, 83, 1663-1681. [CrossRef]

46. Magallón-Puebla, S.; Cevallos-Ferriz, S.R. Latest occurrence of the extinct genus Cedrelospermum (Ulmaceae) in North America: Cedrelospermum Manchesteri from Mexico. Rev. Palaeobot. Palynol. 1994, 81, 115-128. [CrossRef]

47. Garfi, G.; Carimi, F.; Fazan, L.; Gristina, A.S.; Kozlowski, G.; Console Livreri, S.; Motisi, P.; Pasta, S. From glacial refugia to hydrological microrefugia: Factors and processes driving the persistence of the climate relict tree Zelkova sicula. Ecol. Evol. 2021. [CrossRef]

48. Lykholat, Y.; Khromykh, N.; Didur, O.; Alexeyeva, A.; Lykholat, T.; Davydov, V. Modeling the invasiveness of Ulmus pumila in urban ecosystems in conditions of climate change. Regulat. Mech. Biosyst. 2018, 9, 161-166. [CrossRef]

49. Sherman-Broyles, S.L.; Barker, W.T.; Schulz, L.M. Ulmaceae. Flora N. Am. 1997, 3, 368-380.

50. Kozlowski, G.; Frey, D.; Fazan, L.; Egli, B.; Bétrisey, S.; Gratzfeld, J.; Garfi, G.; Pirintsos, S. The tertiary relict tree Zelkova abelicea (Ulmaceae): Distribution, population structure and conservation status on Crete. Oryx 2014, 48, 80-87. [CrossRef]

51. World Conservation Monitoring Centre IUCN Red List of Threatened Species: Ulmus Gaussenii. Available online: https: //www.iucnredlist.org/en (accessed on 4 November 2020).

52. Garfi, G.; Pasta, S.; Fazan, L.; Kozlowski, G. IUCN Red List of Threatened Species: Zelkova Sicula. Available online: https: //www.iucnredlist.org/en (accessed on 6 October 2020).

53. Zhang, Q.; Zhang, H.; Li, Q.; Bai, R.; Ning, E.; Cai, X. Characterization of the complete chloroplast genome sequence of an endangered elm species, Ulmus gaussenii (Ulmaceae). Conserv. Genet. Resour. 2019, 11, 71-74. [CrossRef]

54. Geng, Q.-F.; Yang, J.; He, J.; Wang, D.-B.; Shi, E.; Xu, W.-X.; Jeelani, N.; Wang, Z.-S.; Liu, H. Microsatellite markers for the critically endangered elm species Ulmus gaussenii (Ulmaceae). Genes Genet. Syst. 2016, 91, 11-14. [CrossRef]

55. Garfi, G.; Carimi, F.; Pasta, S.; Rühl, J.; Trigila, S. Additional insights on the ecology of the relic tree Zelkova sicula di Pasquale, garfi et quézel (Ulmaceae) after the finding of a new population. Flora Morphol. Distribut. Funct. Ecol. Plants 2011, 206, 407-417. [CrossRef]

56. Garfi, G.; Buord, S. Relict species and the challenges for conservation: The emblematic Case of Zelkova sicula di pasquale, garfi et quézel and the efforts to save it from extinction. Biodivers. J. 2012, 3, 281-296.

57. Christe, C.; Kozlowski, G.; Frey, D.; Bétrisey, S.; Maharramova, E.; Garfi, G.; Pirintsos, S.; Naciri, Y. Footprints of past intensive diversification and structuring in the genus Zelkova (Ulmaceae) in south-western Eurasia. J. Biogeogr. 2014, 41, 1081-1093. [CrossRef]

58. IUCN. The IUCN Red List of Threatened Species. Available online: https:/ / www.iucnredlist.org (accessed on 11 December 2020).

59. Fazan, L.; Guillet, S.; Corona, C.; Kozlowski, G.; Stoffel, M. Imprisoned in the Cretan mountains: How relict Zelkova abelicea (Ulmaceae) trees cope with Mediterranean climate. Sci. Total Environ. 2017, 599, 797-805. [CrossRef] [PubMed]

60. Stritch, L.; Rivers, M.C.; Barstow, M. IUCN Red List of Threatened Species: Ulmus Americana. Available online: https: //www.iucnredlist.org/en (accessed on 20 October 2020).

61. Gao, J.-G.; Wu, Y.-H.; Xu, G.-D.; Li, W.-Q.; Yao, G.-H.; Ma, J.; Liu, P. Phylogeography of Ulmus elongata based on fourier transform-infrared spectroscopy (FTIR), thermal gravimetric and differential thermal analyses. Biochem. Syst. Ecol. 2012, 40, 184-191. [CrossRef] 
62. Song, J.; Chen, L.; Chen, F.; Ye, J. Edaphic and host plant factors are linked to the composition of arbuscular mycorrhizal fungal communities in the root zone of endangered Ulmus chenmoui Cheng in China. Ecol. Evol. 2019, 9, 8900-8910. [CrossRef] [PubMed]

63. Mughal, A.H.; Mugloo, J.A. Elm (Ulmus wallichiana): A vulnerable lesser known multipurpose tree species of Kashmir valley. SKUAST J. Res. 2016, 18, 73-79.

64. Lopez-Gallego, C.; Morales, M.P.A. IUCN Red List of Threatened Species: Ampelocera albertiae. Available online: https: //www.iucnredlist.org/en (accessed on 9 February 2021).

65. Todzia, C.A.; Panero, J.L. A New species of Ulmus (Ulmaceae) from Southern Mexico and a synopsis of the species in Mexico. Brittonia 1998, 50, 343-347. [CrossRef]

66. Linares, J.L. Primer registro de Ulmus ismaelis (Ulmaceae) para Centroamérica. Rev. Mexicana Biodivers. 2005, 76, 95-96. [CrossRef]

67. Hou, H.; Ye, H.; Wang, Z.; Wu, J.; Gao, Y.; Han, W.; Na, D.; Sun, G.; Wang, Y. Demographic history and genetic differentiation of an endemic and endangered Ulmus lamellosa (Ulmus). BMC Plant Biol. 2020, 20, 526. [CrossRef]

68. Manchester, S.R.; Tiffney, B.H. Integration of paleobotanical and neobotanical data in the assessment of phytogeographic history of holarctic angiosperm clades. Int. J. Plant Sci. 2001, 162, 19-27. [CrossRef]

69. Wu, Z.; Raven, P.H.; Hong, D. Flora of China-Ulmaceae through Basellaceae; Science Press: Beijing, China, 2003 ; Volume 5.

70. Naciri, Y.; Christe, C.; Bétrisey, S.; Song, Y.-G.; Deng, M.; Garfi, G.; Kozlowski, G. Species delimitation in the East Asian species of the relict tree genus Zelkova (Ulmaceae): A complex history of diversification and admixture among species. Mol. Phylogenet. Evol. 2019, 134, 172-185. [CrossRef]

71. Nee, M. Ulmaceae-Flora Mesoamericana. Available online: http://legacy.tropicos.org/Project/FM (accessed on 11 December 2020).

72. Akhter, R. Ulmaecae in Flora of Pakistan. Available online: www.eFloras.org (accessed on 11 December 2020).

73. Wiegrefe, S.J.; Sytsma, K.J.; Guries, R.P. Phylogeny of elms (Ulmus, Ulmaceae): Molecular evidence for a sectional classification. Syst. Bot. 1994, 19, 590-612. [CrossRef]

74. Buchel, A.S. The species of the genus Ulmus. In The Elms, Breeding, Conservation and Disease Management; Kluwer Academic Publishers: Berlin, Germany, 2000; pp. 351-358.

75. Xiao, Y.; Watson, M. Guidance on conducting-A systematic literature review. J. Plann. Educ. Res. 2019, 39, 93-112. [CrossRef]

76. Little, J.; Elbert, L. Atlas of United States Trees. In Conifers and Important Hardwoods; USDA Forest Service Miscellaneous Publication: Washington, DC, USA, 1971; Volume 1, p. 1146.

77. Melville, R.; Heybroek, H.M. The elms of the Himalaya. Kew Bull. 1971, 26, 5-28. [CrossRef]

78. Fu, L.; Xin, Y. Elms of China. In The Elms; Springer: Boston, MA, USA, 2000; pp. 21-44.

79. Caudullo, G.; Welk, E.; San-Miguel-Ayanz, J. Chorological maps for the main European woody species. Data Brief 2017, 12, 662-666. [CrossRef] [PubMed]

80. Pederneiras, L.C.; Machado, A.F.P.; Pederneiras, L.C.; Machado, A.F.P. Flora do estado do Rio de Janeiro: Ulmaceae. Rodriguésia 2017, 68, 541-543. [CrossRef]

81. GBIF. GBIF: The Global Biodiversity Information Facility. Available online: https://www.gbif.org (accessed on 29 September 2020).

82. Gradstein, S.R. Catálogo de Plantas y Líquenes de Colombia; En Bernal, R., Gradstein, S.R., Celis, M., Eds.; Instituto de Ciencias Naturales, Universidad Nacional de Colombia: Bogotá, Colombia, 2015.

83. Royal Botanic Gardens Kew. Plants of the World Online. Available online: http:/ / www.plantsoftheworldonline.org (accessed on 29 September 2020).

84. QGIS. Development Team QGIS Geographic Information System. Available online: http:/ / qgis.org (accessed on 12 November 2020).

85. GADM. GADM Database of Global Administrative Areas. Available online: https:/ /gadm.org/ (accessed on 26 February 2021).

86. Natural Earth Data. Natural Earth-Free Vector and Raster Map Data at 1:10 m, 1:50 m, and 1:110 m Scales. Available online: https: / / www.naturalearthdata.com/ (accessed on 26 February 2021).

87. Peel, M.C.; Finlayson, B.L.; McMahon, T.A. Updated world map of the Köppen-Geiger climate classification. Hydrol. Earth Syst. Sci. 2007, 11, 1633-1644. [CrossRef]

88. Beck, H.E.; Zimmermann, N.E.; McVicar, T.R.; Vergopolan, N.; Berg, A.; Wood, E.F. Present and future Köppen-Geiger climate classification maps at 1-km resolution. Sci. Data 2018, 5, 1-12. [CrossRef]

89. Fick, S.E.; Hijmans, R.J. WorldClim 2: New 1-km spatial resolution climate surfaces for global land areas. Int. J. Climatol. 2017, 37, 4302-4315. [CrossRef]

90. Earth Resources Observation and Science (EROS). Center shuttle radar topography mission (SRTM) 1 arc-second global. USGS 2017. [CrossRef]

91. O'Donnell, M.S.; Ignizio, D.A. Bioclimatic predictors for supporting ecological applications in the conterminous United States. US Geol. Surv. Data Ser. 2012, 691, 4-9.

92. Goedecke, F.; Bergmeier, E. Ecology and potential distribution of the Cretan endemic tree species Zelkova abelicea. J. Mediterr. Ecol. 2018, 16, 15-26.

93. R Core Team. R: A Language and Environment for Statistical Computing; R Foundation for Statistical Computing: Vienna, Austria, 2018.

94. Kruskal, J.B. Nonmetric multidimensional scaling: A numerical method. Psychometrika 1964, 29, 115-129. [CrossRef] 
95. Oksanen, J.; Kindt, R.; Legendre, P.; O’Hara, B.; Stevens, M.H.H.; Oksanen, M.J.; Suggests, M. The Vegan Package. Commun. Ecol. Package 2007, 10, 719.

96. Borcard, D.; Gillet, F.; Legendre, P. Numerical Ecology with R; Springer: New York, NY, USA, 2018; ISBN 3-319-71404-X. 